\title{
臨床報告 気管支喘息における病血病態の解析
}

\author{
村上 和憲 ${ }^{1)}$ 江頭 洋祐 ${ }^{2)}$
}

Analysis of Oketsu (blood stagnation) State in the Pathophysiology of Bronchial Asthma

\section{Kazunori MURAKAMI $^{1)} \quad$ Yosuke EGASHIRA $^{2)}$}

1) M.D., Department of Laboratory Medicine Kumamoto University School of Medicine

2 ) M.D., Department of Internal Medicine, Tamana Central Hospital

\begin{abstract}
Abstiact It is known that Kiutsu state (obstruction of qi) is frequently observed in bronchial asthma. We found that Oketsu (blood stagnation) state is also observed in such patients. In the present study, we analyzed the Oketsu state in 70 asthma patients. Oketsu state was evaluated by Oketsu score (OS) by Dr. Terasawa. OS was significantly elevated in asthmatic patients, and it increased depending on the severity of the asthma. OS was no different in atopic asthma and non-atopic asthma. OS was significantly high in oral steroid treated patients. However, when the object is restricted only in the moderate state, OS was no different between the steroid treated group and the non-steroid treated group. From these results, we conclude that the Oketsu state is deeply interacted with asthma and that low dose oral steroid administration does not seem to worsen the Oketsu state in patients with asthma. We should follow the OS before and after the administration of steroids to test this hypothesis. We will investigate it in the near future.
\end{abstract}

Key words : bronchial asthma, Oketsu, steroid, severity

Nihon Toyo Igaku Zasshi(Japanese Journal of Oriental Medicine), $\mathbf{5 0}(2), 241-245,1999$

(Accepted ; 10 Dec., 1998)

緒 言

気管支喘息の漢方治療においては，気鬱に対し て半夏厚朴湯や柴朴湯などの理気剂が，気管支の 狭窄に対して小青竜湯や麻杏甘石湯などの麻黄剂 が多く用いられている1)。一方，古典に「久病は 瘀血を生ず」とあるが，喘息は気管支を主体とし た慢性の炎症性疾患であるから，経過とともに㾉 血病態が出現するのではないかと考えた。これま
で，文献的には気管支喘息における痳血病態を論 じたものはほとんどなく，江頭らの報告が最初の 論文と思われる2)。さらに，江頭らは，気管支喘 息患者で，著明な瘀血病態を示した患者に対し， 駆㾉血剤として桂枝茯苓丸を用いて喘息病態が改 善した症例を報告している3)。そこで，今回われ われは，気管支喘息患者70名について，瘀血病態 がどのような形で関与しているかについてさらに 解析を加えたので報告する。

1 ) 医, 熊本大学医学部臨床検査医学, 熊本, $\bar{\top} 860-8556$ 熊本市本荘1-1-1

2 ）医，公立玉名中央病院

〔1998年12月10日受理〕 
表 1

患者

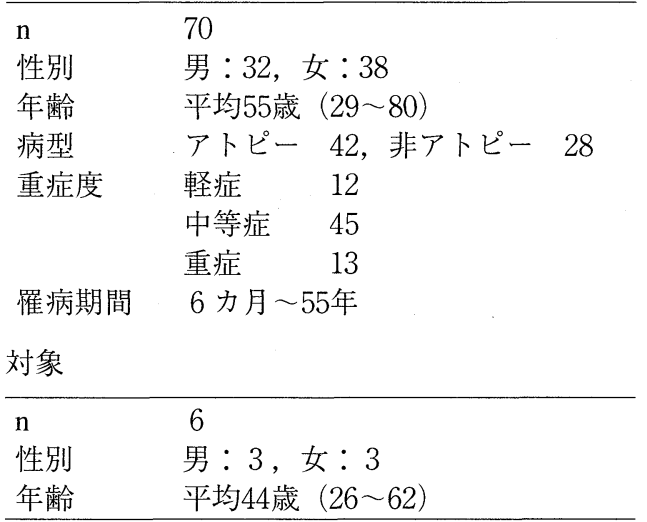

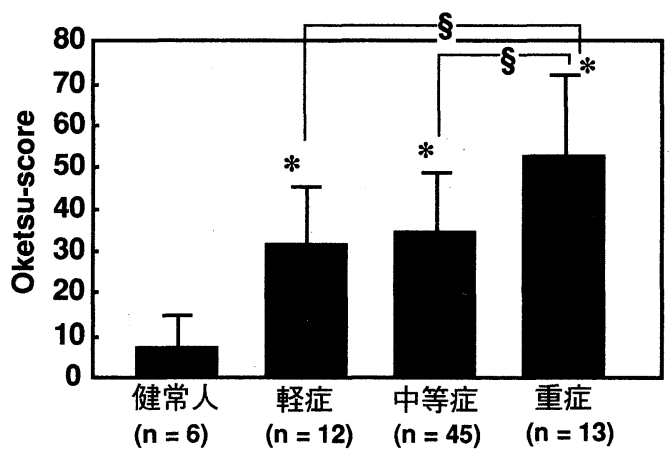

図 1 喘息患者における重症度と㾉血スコアの関係 平均 $\pm \mathrm{SD}$. $* \mathrm{P}<0.05 \mathrm{vs}$. 健常人, $\S \mathrm{p}<0.05 \mathrm{vs}$. 重症。

\section{対象および方法}

公立玉名中央病院の内科外来を受診した気管支 喘息患者70名について瘀血の状態，重症度，罹患 年数，経ロステロイド投与量（プレドニゾロン換 算)，アトピー性，非アトピー性の別などについ て検討した。比較対象として，健常人 6 名につい て検討した。重症度は，日本アレルギー学会の気 管支喘息重症度判定委員会基準 ${ }^{4)}$ 準じた。瘀血 の状態は，寺澤の疙血スコア ${ }^{5)}$ をいてスコア化 し，比較検討した。2 群間の比較は, unpaired t-test を行い，多群間の比較は，分散分析 (ANOVA) の後, Scheffés Post-hoc testによる多重比較検定 を行い，それぞれ，p<0.05にて有意と判断した。 相関の有無は，統計処理ソフト Stat View II で検

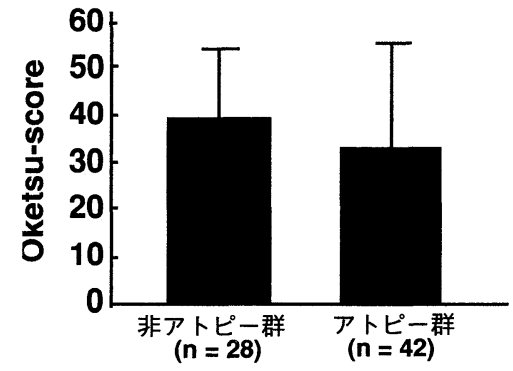

図 2 瘀血患者における病型の違いと 瘀血スコアの関係 平均 $\pm \mathrm{SD}$.

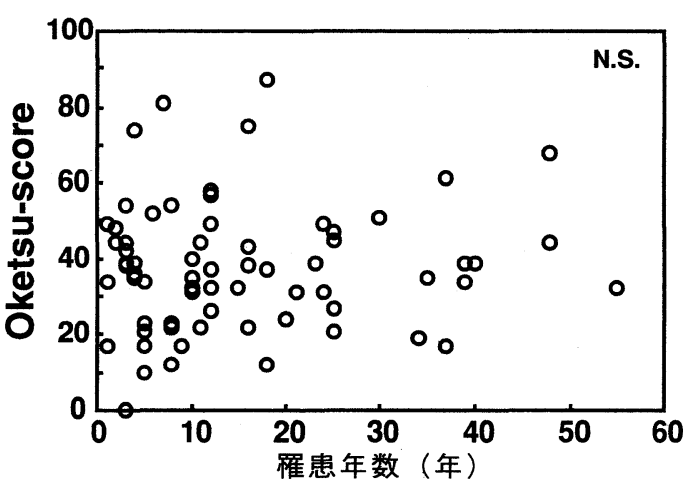

図 3 罹患年数と瘀血スコアの関係

討し， $\mathrm{p}<0.05$ で有意と判断した。

結 果

1 ）気管支喘息患者における重症度と瘀血スコ アの関係

対象となった患者70名および対照 6 名の背景を 表 1 に示す。健常人では㾉血スコアは正常範囲で あった。一方，喘息患者では，軽症患者でも健常 人に比べて有意に疼血スコアが高值を示した。さ らに，重症度が増すにつれて瘀血スコアも上昇し た。軽症群と重症群，中等症群と重症群の間にも それぞれ有意な差を認めた（図１）。

2 ) 気管支喘息患者に招ける病型の違いと㾉血 スコアの関係

対象となる患者70名について，アトピー群と非 アトピー群に分けたところ，それぞれ 28 名と 42 名 であった。それぞれの群で，瘀血スコアに差があ るか否かを検討したところ，いずれも健常人より 


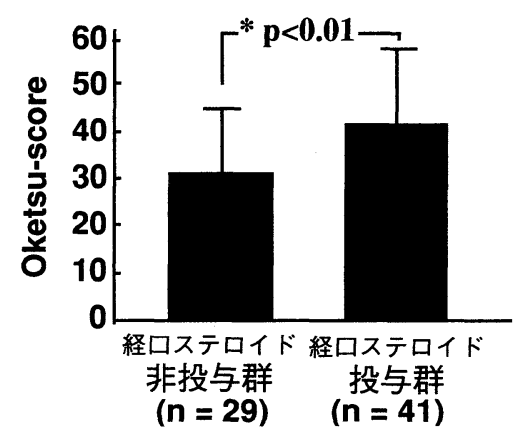

図4喘息患者における経口ステロイ ド投与の有無と瘀血スコアの関係 平均 $\pm \mathrm{SD}$.

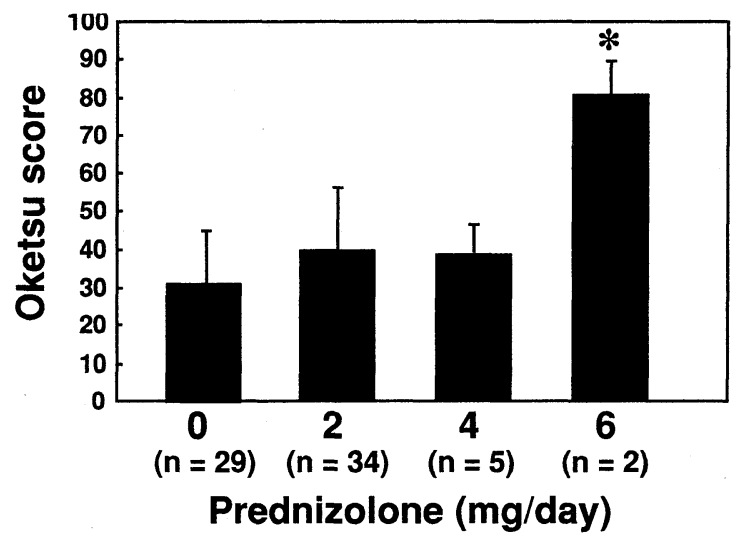

図 5 経ロステロイド投与量（プレドニゾロン換算） と疼血スコアの関係

平均 $\pm \mathrm{SD} . * \mathrm{P}<0.01 \mathrm{vs}$. ステロイド非投与群。

は高いが，各群間に有意差は認めなかった（図 2)。

3 ) 気管支喘息の罹患年数と疼血スコアの関係 患者の罹患年数が, 瘀血スコアとどのような関 係にあるか検討した。図 3 に示したとおり，発症 間もない患者群でも瘀血スコアが高い症例が多く, 両者の間には有意な相関は認めなかった。

4 ) 瘀血スコアと経口ステロイド投与の関係

まず，対象となった気管支喘息患者70名を，経 ロステロイド投与群と非投与群に分けると，それ ぞれ，29人，41人となった。両群間に疼血スコア の違いがあるか検討したところ，ステロイド投与 群では有意に㾥血スコアが高值を示した（図４）。 次に，瘩血スコアと経ロステロイド投与量の関係

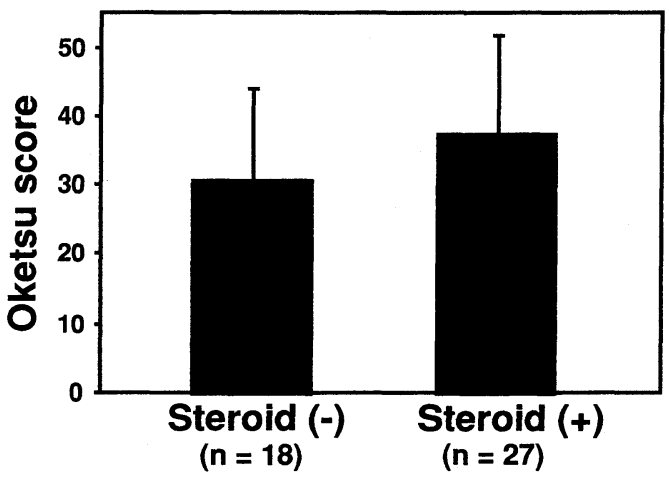

図6 喘息患者（中等症）における経ロステロ イド投与の有無と疼血スコアの関係 平均 $\pm \mathrm{SD}$.

について検討した。その結果，経ロステロイド投 与量が最も多い, $6 \mathrm{mg} /$ 日の群のみがほかのい ずれの群に対しても有意に高值を示した（図 5 )。 つきに，重症度の差を排除して検討するため，中 等症の患者45名において, 経口ステロイド投与群 と非投与群に分け，瘀血スコアを検討した。その 結果, 瘀血スコアは経ロステロイド投与群では非 投与群より高值を示す傾向にあったが，有意差は 認められなかった（図6）。

\section{考 察}

本研究では，気管支喘息患者における㾉血病態 の存在について明らかにした。寺澤らは, 瘀血の 病態についての基礎的研究を通して, 瘀血とは赤 血球の微小循環不全が大きい関与をしていると報 告しており，血液粘度の上昇や微小循環での赤血 球の流速の著明な低下を証明している ${ }^{6)}$ 。気管支 喘息患者を見ても, 眼輪の色素沈着や, 歯肉の暗 赤色化などの瘀血を疑う変化が多く見られること は, 臨床家の素直な感想であろう。そこで, 我々 は，気管支喘息患者において，寺澤の疙血スコア をもちいて瘀血病態の有無を観察し, 重症度や経 ロステロイド投与の影響などについて検討した。

図 1 で示したように，喘息の重症度が増すにした がって㾉血病態が進行するということは, 喘息の 病態が血液粘度や微小循環系に影響を及ぼしてい るものと考えられる。気管支喘息は，気管支を炎 
症の場としたアレルギー性の炎症であるが，それ が全身の微小循環に影響を及ほしているというこ とを意味する。

今回, 病血の診断は寺澤の疼血スコアを用いて 判定したが，西洋医学あるいは現代科学の力をか り，血液粘度や赤血球变形能々の他の指標を用い てこのことを証明できれば，漢方医学の診断法が いかに簡便で優れたものであるかを示すことがで きるのではないかと思う。今回の検討では，手技 的な問題もあり，臨床検查医学的検討はできてい ないが，㾉血病態と喘息の重症度との間にはっき りした相関を認めたので, 今後, 現代医学の検査 手法を用いて，同様の結果を証明できると確信し ている。

喘息に疾血病態が重要な関連をしているという ことであれば，当然，駆疼血剤を使用して，病態 が改善するのかという疑問がわいてくる。事実， 我々は，気管支喘息で，高度な㾉血を呈している 患者に対して，桂枝获苓丸を投与し，瘀血ととも に喘息症状も軽減した症例を経験している ${ }^{3)}$ 。日 本では，医療用漢方エキス製剂の中で活血化疼作 用を期待できる薬剂は桂枝获苓丸や桃核承気湯程 度しかないため，前出の症例では桂枝获苓丸を用 いたが，本剤には利水作用があるために体を乾燥 させすぎ，場合によっては間質性肺炎などの副作 用を起こす危険性があるという指摘がある。最近 の中西医結合医学のテキストを参照したが，喘息 に対する駆瘀血剤の使用については今のところ記 載が見られないフ。

今回，罹患年数と疼血病態にはまったく相関が 認められなかった。㾉血という病態は，長い炎症 反応の経過の結果生じてくるものと予想していた が，結果は意外なものであった。罹患して数年以 内に高度の瘀血病態を呈する患者が多かったとい うことは，おそらく，疼血病態は我々が想像して いる以上にダイナミックに生じたり消失したりす るのだろうと考えられる。

ステロイドの投与は疙血病態を惹起するのかど うかというのは，もうひとつの疑問である。ステ ロイドはプロスタグランディン（PG）産生に重 要なホスホリパーゼを阻害するため, 血管を拡張
し，微小循環を制御している PGI 2 の産生を抑制 し，それだけでも微小循環を悪化させる可能性が 考えられる。一方，ステロイドは好中球やリンパ 球，好酸球などの炎症反応を抑制することで血管 内皮細胞障害を軽減する可能性もある。したがっ て，結果的にステロイドは微小循環を改善するの か，悪化するのかは疑問であった。今回の検討に より，瘀血病態はステロイド投与群で明らかに高 值を示した。しかし，ステロイド投与量と㾉血ス コアの間に用量依存的な相関は見られず， $6 \mathrm{mg}$ ／日の群のみ高スコアを示した。これは，ステロ イドを多く必要とする患者はほとんど重症に属す るため，ステロイド投与前から㾉血スコアが高值 を示していた可能性もあり，ステロイドが疼血を 悪化させたと短絡的には結論できない。このこと は，ステロイド投与前のスコアと投与後のスコア の経時的な変化を各症例で検討することによりさ らに明らかになるであろう。同じ重症度（中等 症）の中で経口ステロイド投与群と非投与群の瘀 血スコアを検討してみたところ，経口ステロイド 投与群では若干の高值を示したものの，有意な差 は認められなかった。このことより，プレドニゾ ロン $2 \mathrm{mg} /$ 日程度の投与は，瘀血スコアに大き い影響は与えない可能性が示された。

㾉血の病態には，気滞疼血というものがあり， 気の滞りが疙血を生じるといわれている。気管支 喘息では，気滞の病態が深くかかわっているため， 瘀血が生じることは理解できる。ここで興味ある ことは，半夏厚朴湯や柴朴湯を用いて，理気を行 うことによってどのくらい㾉血が改善するかとい うことと，活血化疙薬を加味するなら，どのよう な生薬をどのくらい加えたらよいかということで ある。今後，そのような問題を解決するためにも， 本研究の結果をふまえ，さらに検討を加えていき たい。

\section{文 献}

1 ）江頭洋祐：気管支喘息・気管支炎・肺気腫の漢 方治療（症例で見る診療のポイント）. 9-78, 現代出版プランニング，東京（1997）

2 ) 江頭洋祐：ステロイド依存性気管支喘息患者の 疼血病態について，漢方と免疫・アレルギー 
8, 122-131 (1994)

3 ) 江頭洋祐, 西山敬一郎, 村上和憲: ステロイド 依存性喘息患者の疙血病態への凝固系指標によ るアプローチ, 漢方と免疫・アレルギー 11, 40 -51 (1997)

4 ）気管支喘息重症度判定基準再検討委員会報告, アレルギー 43，71-80（1994）
5 ）寺澤捷年: 気血水の概念による病態の把握, 和 漢診療学, 医学書院, 東京, 248-250（1990）

6 ) 寺澤捷年: 疙血病態の科学的解明, 日本東洋医 学雑誌 48, 409-436 (1998)

7 ) 陳貴延主編: 実用中西医結合診断治療学, 中国 医薬科技出版社, 北京, 259-268（1991）

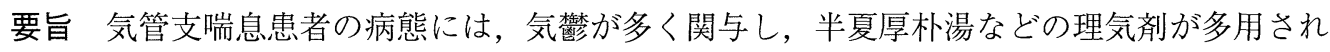
る。一方，臨床的には，瘀血症状が多々みうけられる様だが，文献上そのような報告はほとん ど見られない。そこで，気管支喘息には㾉血病態がどのようにかかわっているのかについて， 外来通院中の70名の患者について詳細に検討した。㾉血スコアは, 喘息の重症度が増すにつれ て有意に高值を示した。罹患年数と㾉血スコアは相関せず，発症初期から高度の瘀血を呈する 人が多いことが判明した。経ロステロイドを使用している患者では, 非使用群に対して㾉血ス コアが有意に高かったが，重症度を中等度に限定して検討したところ，経口ステロイドの㾉血 スコアへの影響はあまり顕著には認められなかった。以上の結果より，気管支喘息患者に疼血 病態が存在し, 重症な症例ほど高度の㾉血を合併すること, および, 少量経口ステロイド投与 の疼血への影響はあまり大きくないことが明らかとなった。

キーワード：気管支喘息, 㾉血, ステロイド, 重症度 